\title{
Management of health care workers following occupational exposure to hepatitis $B$, hepatitis $C$, and human immunodeficiency virus
}

\author{
Winnie WY Sin, Ada WC Lin, Kenny CW Chan *, KH Wong
}

\section{A B S T R A C T}

Introduction: Needlestick injury or mucosal contact with blood or body fluids is well recognised in the health care setting. This study aimed to describe the post-exposure management and outcome in health care workers following exposure to hepatitis $\mathrm{B}$, hepatitis $\mathrm{C}$, or human immunodeficiency virus (HIV) during needlestick injury or mucosal contact.

Methods: This case series study was conducted in a public clinic in Hong Kong. All health care workers with a needlestick injury or mucosal contact with blood or body fluids who were referred to the Therapeutic Prevention Clinic of Department of Health from 1999 to 2013 were included.

Results: A total of 1525 health care workers were referred to the Therapeutic Prevention Clinic following occupational exposure. Most sustained a percutaneous injury (89\%), in particular during postprocedure cleaning or tidying up. Gloves were worn in $62.7 \%$ of instances. The source patient could be identified in $83.7 \%$ of cases, but the infection status was usually unknown, with baseline positivity rates of hepatitis B, hepatitis C, and HIV of all identified sources, as reported by the injured, being $7.4 \%, 1.6 \%$, and $3.3 \%$, respectively. Post-exposure prophylaxis
This article was published on 26 Aug 2016 at www.hkmj.org. whom 14 (38.9\%) had been exposed to known HIV- infected blood or body fluids. The majority (89.6\%) received HIV post-exposure prophylaxis within 24 hours of exposure. Drug-related adverse events were encountered by $88.6 \%$. The completion rate of postexposure prophylaxis was $73.1 \%$. After a follow-up period of 6 months (or 1 year for those who had taken HIV post-exposure prophylaxis), no hepatitis $B$, hepatitis C, or HIV seroconversions were detected.

Conclusions: Percutaneous injury in the health care setting is not uncommon but post-exposure prophylaxis of HIV is infrequently indicated. There was no hepatitis B, hepatitis C, and HIV transmission via sharps or mucosal injury in this cohort of health care workers.

\section{Hong Kong Med J 2016;22:472-7}

DOI: 10.12809/hkmj164897

WWY Sin, MB, ChB, FHKAM (Medicine)

AWC Lin, MB, BS, FHKAM (Medicine)

KCW Chan *, MB, BS, FHKAM (Medicine)

KH Wong, MB, BS, FHKAM (Medicine)

Special Preventive Programme, Centre for Health Protection, Department of Health, Kowloon Bay Health Centre, Hong Kong

* Corresponding author: kcwchan@dh.gov.hk

New knowledge added by this study

The risk of hepatitis B (HBV), hepatitis C (HCV), and human immunodeficiency virus (HIV) transmission following occupational sharps or mucosal injury in Hong Kong is small.

Implications for clinical practice or policy

- Meticulous adherence to infection control procedures and timely post-exposure management prevents HBV, $\mathrm{HCV}$, and HIV infection following occupational exposure to blood and body fluids.

\section{Introduction}

Needlestick injury or mucosal contact with blood or body fluids is well recognised in the health care setting. These incidents pose a small but definite risk for health care workers of acquiring blood-borne viruses, notably hepatitis B virus (HBV), hepatitis $\mathrm{C}$ virus (HCV), and human immunodeficiency virus (HIV). The estimated risk of contracting HBV infection through occupational exposure to known infected blood via needlestick injury varies from $18 \%$ to $30 \%$, while that for $\mathrm{HCV}$ infection is $1.8 \%$ (range, $0 \%-7 \%){ }^{1}$ The risk of HIV transmission following percutaneous or mucosal exposure to HIVcontaminated blood is $0.3 \%$ and $0.09 \%$, respectively. ${ }^{1}$ The risk is further affected by the type of exposure, body fluid involved, and infectivity of the source.

In Hong Kong, injured health care workers usually receive initial first aid and immediate management in the Accident and Emergency Department. They are then referred to designated clinics for specific post-exposure management. Currently, aside from staff of the Hospital Authority who are managed at two designated clinics postexposure, all other health care workers from 
private hospitals, and government or private clinics and laboratories are referred to the Therapeutic Prevention Clinic (TPC) of the Integrated Treatment Centre, Department of Health. Since its launch in mid-1999, the TPC has provided comprehensive post-exposure management to people with documented percutaneous, mucosal, or breached skin exposure to blood or body fluids in accordance with the local guidelines set out by the Scientific Committee on AIDS and STI, and Infection Control Branch of Centre for Health Protection, Department of Health. $^{2}$ The present study describes the characteristics and outcome of health care workers who attended the TPC from mid-1999 to 2013 following occupational exposure to blood or body fluids.

\section{Methods}

The study included all health care workers seen in the TPC from July 1999 to December 2013 following occupational exposure to blood or body fluids, who attended following secondary referral by an accident and emergency department of a public hospital. Using two standard questionnaires (Appendices), data were collected by the attending nurse and doctor during a face-to-face interview with each health care worker on the following: demography and occupation of the exposed client, type and pattern of exposure, post-exposure management, and clinical outcome.

Details of the exposure, including type of exposure and the situation in which it occurred, were noted. The number of risk factors (see definitions below) for HIV transmission was counted for each exposure and further classified as high risk or low risk. Where known and reported by the injured party, hepatitis B surface antigen ( $\mathrm{HBsAg}$ ), $\mathrm{HCV}$, and HIV status of the source were recorded.

The timing of the first medical consultation in the accident and emergency department, any prescription of HIV post-exposure prophylaxis (PEP), and the time since injury were noted. Exposed health care workers who received HIV PEP were reviewed at clinic visits every 2 weeks until completion of the 4-week course of treatment, and any treatment-related adverse effects were reported. Blood was obtained as appropriate at these visits for measurement of complete blood count, renal and liver function, and amylase, creatine kinase, fasting lipid, and glucose levels.

Apart from HIV PEP-related side-effects (reported and rated by patients as mild, moderate, or severe), the rate of completion of PEP, and number of $\mathrm{HBV}, \mathrm{HCV}$, and HIV seroconversions following the incident was also recorded. The HBsAg, anti-HBs, anti-HCV, and anti-HIV were checked at baseline and 6 months post-exposure to determine whether seroconversion had occurred. Those exposed to a

\section{醫護人員職業暴露乙型肝炎、丙型肝炎和人類 免疫力缺乏病毒後的處理 \\ 冼顒然、連慰慈、陳志偉、黃加慶}

引言：醫護人員就職業性針刺意外和黏膜接觸病人血液和體液而暴露 於乙型肝炎、丙型肝炎和人類免疫力缺乏病毒（HIV）時有發生。本 研究旨在描述這些意外暴露後的處理與結果。

方法：這病例系列研究在香港一間公立診所內進行。研究對象包括所 有於1999年至2013年期間因職業性針刺意外或秥膜接觸血液或體液而 於衞生署預防治療診所求診的醫護人員。

結果：在1525名求診的醫護人員中以穿透皮膚的接觸最常見（89\%）, 而意外發生往往與清潔或收拾器具的程序有關。意外中手套使用率為 $62.7 \%$ 。個案中有 $83.7 \%$ 可追溯血液或體液的來源, 當中乙型肝炎、丙 型肝炎和HIV的感染率分別為 $7.4 \%$ 、 $1.6 \%$ 、和 $3.3 \%$, 其餘來源的感染 情況大多不詳。48名醫護人員接受HIV暴露後的預防藥物, 當中包括 14 名（38.9\%）曾接觸HIV感染者的血液或體液。大多數 $(89.6 \%)$ 暴 露後的預防藥物於 24 小時內處方, 有 $88.6 \%$ 服藥後感到不適， $73.1 \%$ 能完成整個療程。經過6個月的覆診（曾服用HIV暴露後的預防藥物 的覆診期為 1 年），並沒有錄到新感染乙型肝炎、丙型肝炎和HIV的個 案。

結論：醫療機構內經皮膚的針刺意外並不罕見, 大多數個案母須處方 $\mathrm{HIV}$ 暴露後的預防藥物。本研究並沒有因職業性接觸引致新增的乙型 肝炎、丙型肝炎和HIV感染。

known HCV-infected source or a source known to be an injecting drug user had additional blood tests 6 weeks post-exposure for liver function, anti-HCV, and HCV RNA. Additional HIV antibody testing at 3 and 12 months post-exposure was arranged for those who received HIV PEP. For those who contracted $\mathrm{HCV}$ infection from a source co-infected with $\mathrm{HCV}$ and HIV, further HIV testing was performed at 1 year post-exposure to detect delayed seroconversion.

\section{Definitions}

Health care workers included doctors and medical students, dentists and dental workers, nurses, midwives, inoculators, laboratory workers, phlebotomists, ward or clinic attendants, and workmen. Staff working in non-health care institutions (eg elderly home, hostels, and sheltered workshops) were excluded. Five factors were classified as high-risk exposure: (i) deep percutaneous injury, (ii) procedures involving a device placed in a blood vessel, (iii) use of a hollow-bore needle, (iv) device that was visibly contaminated with blood, and (iv) source person with acquired immunodeficiency syndrome (AIDS). ${ }^{3}$ Another five factors were classified as lowrisk exposure: (i) moderate percutaneous injury, (ii) mucosal contact, (iii) contact with deep body fluids other than blood, (iv) source person was HIVinfected but not or not sure about the stage of AIDS, 


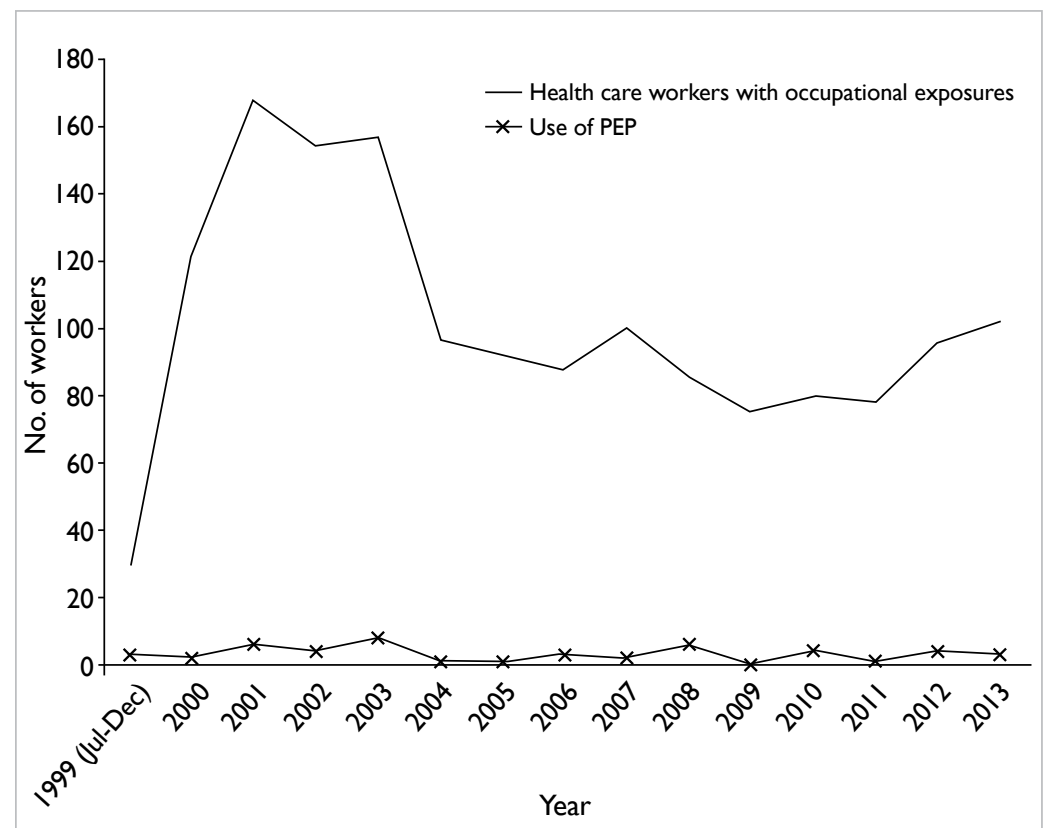

FIG. Referrals of health care workers with occupational exposure to Therapeutic Prevention Clinic and the post-exposure prophylaxis (PEP) prescription and (v) any other reason contributing to increased risk according to clinical judgement.

\section{Results}

From July 1999 to December 2013, 1525 health care workers (75-168 per year) with occupational exposure to $\mathrm{HBV}, \mathrm{HCV}$, or HIV were referred to the TPC (Fig). Females constituted $77 \%$ of all attendees. The median age was 33 years (range, 17-73 years). The majority came from the dental profession (36.8\%) and nursing profession (33.4\%), followed by ward/clinic ancillary staff (11.6\%) and the medical profession (4.7\%).

\section{Type and pattern of exposure}

The majority of exposures occurred in a public clinic or laboratory $(n=519,34.0 \%)$, followed by public hospital $(n=432,28.3 \%)$, private clinic or laboratory $(\mathrm{n}=185,12.1 \%)$, and private hospital $(\mathrm{n}=23,1.5 \%)$. Most were a percutaneous injury (88.9\%). Mucosal contact, breached skin contact, and human bite were infrequent (Table 1). Approximately $60 \%$ of the incidents occurred in one of the four situations: (a) cleaning/tidying up after procedures (the most common), (b) other bedside/treatment room procedures, (c) injection, including recapping of needles, or (d) blood taking/intravenous catheter insertion. The contact specimen was blood or blood products, blood-contaminated fluid, and saliva or urine in $30.6 \%, 5.8 \%$, and $14.1 \%$ of the cases, respectively. The technical device involved was a hollow-bore needle in $48.1 \%$, dental instrument in $20.7 \%$, and lancet in $7.7 \%$. More than $80 \%$ considered the injury superficial.

High-risk and low-risk factors were noted in 869 (57\%) and 166 (11\%) exposures, respectively. Blood taking/intravenous catheter insertion carried the highest risk among all the procedures, with a mean risk factor of 1.29 (Table 2). Gloves were used in 956 (62.7\%) exposures, goggles/mask in 50 (3.3\%), and gown/apron in 55 (3.6\%). Nonetheless, 101 $(6.6 \%)$ health care workers indicated that they did not use any personal protective equipment during the exposure.

The source patient could be identified in 1277 (83.7\%) cases but the infectious status was unknown in most. The baseline known positivity rate for HBV, $\mathrm{HCV}$, and HIV of all identified sources was $7.4 \%$, $1.6 \%$, and $3.3 \%$, respectively (Table 1 ).

\section{Care and clinical outcome}

Nearly half of the injured health care workers attended a medical consultation within 2 hours $(\mathrm{n}=720,47.2 \%)$ and another $552(36.2 \%)$ attended between 2 and 12 hours following exposure. The median time between exposure and medical consultation was 2.0 hours.

During the study period, 48 (3.1\%) health care workers received HIV PEP for occupational exposure, ranging from zero to eight per year (Fig). One third received PEP within 2 hours of exposure, and the majority $(89.6 \%)$ within 24 hours. The median time to PEP was 4.0 hours post-exposure (interquartile range, 2.0-8.1 hours). A three-drug regimen was prescribed in $85.7 \%$ of cases. The most common regimen was zidovudine/lamivudine/indinavir (39.6\%), followed by zidovudine/lamivudine/ ritonavir-boosted lopinavir (31.3\%), and zidovudine/ lamivudine (12.5\%) [Table 3]. Upon consultation and risk assessment at the TPC, 36 (75\%) workers had treatment continued from the accident and emergency department. Among them, the source was confirmed to be HIV-positive in 14 (38.9\%) cases. Of the 35 clients with known outcome, drug-related adverse events were seen in 31 (88.6\%) health care workers; more than half $(n=18,58.1 \%)$ of which were considered to be moderate or severe. Treatmentrelated side-effects led to early termination of PEP in eight (22.9\%) health care workers. Excluding nine clients in whom prophylaxis was stopped when the source was established to be HIV-negative, 19 (73.1\%) clients were able to complete the 28-day course of PEP. Of the 14 clients who sustained injury from an HIV-infected source patient, all received PEP but two did not complete the course; the completion rate was $85.7 \%$.

At baseline, none of the injured health care workers tested positive for HCV or HIV, while 49 
(3.2\% of all health care workers seen in TPC) tested HBsAg-positive. Almost half of the health care workers ( $n=732,48.0 \%$ ) were immune to HBV (antiHBs positive). After follow-up of 6 months (1 year for those who took PEP), no case of HBV, HCV, or HIV seroconversion was detected in this cohort.

\section{Discussion}

Health care workers may be exposed to blood-borne viruses when they handle sharps and body fluids. Thus, adherence to standard precautions of infection control is an integral component of occupational health and safety for health care workers. In this cohort, percutaneous injury with sharps during cleaning or tidying up after procedures remained the most common mechanism of injury. Many of these incidents could have been prevented by safer practice, for instance, by not recapping needles or by disposing needles directly into a sharps box after use. The use of gloves as part of standard precautions was suboptimal and greater emphasis on the importance of wearing the appropriate personal protective equipment should be made during staff training at induction and on refresher courses. Technical devices with safety needleless features may reduce sharps injuries. Improvement in the system (eg by placing a sharps box near the work area) or the workflow to minimise distraction may also help compliance with infection control measures.

Once exposure occurs, PEP is the last defence against HBV and HIV. For HBV infection, PEP with hepatitis $B$ immunoglobulin followed by hepatitis $B$ vaccination has long been the standard practice in Hong Kong. For HIV infection, the efficacy of PEP in health care workers following occupational exposure was demonstrated by a historic landmark overseas case-control study. ${ }^{3}$ Prescription of zidovudine achieved an $81 \%$ reduction in risk of HIV seroconversion following percutaneous exposure to HIV-infected blood. ${ }^{3}$ Local and international guidelines now recommend a combination of three antiretroviral drugs for PEP., ${ }^{2,4-6}$ In this cohort, although more than half of the exposures had higher risk factors for HIV acquisition, it was uncommon for the source patients to have known HIV infection (2.8\% of these exposures). Thus, in accordance with the local guideline, PEP was not commonly prescribed. Nevertheless, PEP was prescribed in all 14 exposures to a known HIV-positive source and in other 34 exposures after risk assessment. Our experience is comparable with the health care service in the UK and US. In the UK, $78 \%$ of health care workers exposed to an HIV-infected source patient were prescribed PEP. ${ }^{7}$ In a report from the US, only $68 \%$ of health care workers with such exposure took PEP. ${ }^{8}$ For HCV, PEP with antiviral therapy is not recommended according to the latest guidelines from American Association for the Study
TABLE I. Details of occupational exposure in health care workers

\begin{tabular}{|c|c|}
\hline Occupational exposure & $\begin{array}{c}\text { No. }(\%) \text { of health care } \\
\text { workers }(n=1525)\end{array}$ \\
\hline \multicolumn{2}{|l|}{ Nature of exposure } \\
\hline Percutaneous & $1356(88.9)$ \\
\hline Mucosal & $50(3.3)$ \\
\hline Non-intact skin & $30(2.0)$ \\
\hline Human bite & $59(3.9)$ \\
\hline Others & $30(2.0)$ \\
\hline \multicolumn{2}{|l|}{ Severity } \\
\hline Superficial & $1263(82.8)$ \\
\hline Moderate & $196(12.9)$ \\
\hline Deep & $3(0.2)$ \\
\hline Not applicable/unknown & $63(4.1)$ \\
\hline \multicolumn{2}{|l|}{ Procedure involved } \\
\hline Blood taking/intravenous catheter insertion & $158(10.4)$ \\
\hline Injection including recapping of needles & $218(14.3)$ \\
\hline Other bedside/treatment room procedures & $252(16.5)$ \\
\hline Cleaning/tidying up after procedures & $298(19.5)$ \\
\hline Other procedure & $534(35.0)$ \\
\hline Others & $65(4.3)$ \\
\hline \multicolumn{2}{|l|}{ Contact specimen } \\
\hline Blood/blood products & $467(30.6)$ \\
\hline Blood-contaminated fluid & $89(5.8)$ \\
\hline Saliva/urine & $215(14.1)$ \\
\hline Other/unknown & $754(49.4)$ \\
\hline \multicolumn{2}{|l|}{ Technical device } \\
\hline Hollow-bore needle & $733(48.1)$ \\
\hline Lancet & $118(7.7)$ \\
\hline Dental instrument & $315(20.7)$ \\
\hline Others & $195(12.8)$ \\
\hline Nil & $164(10.8)$ \\
\hline \multicolumn{2}{|l|}{ Reported status of source (known in 1277 subjects) } \\
\hline Known HBsAg positive & $95\left(7.4^{\star}\right)$ \\
\hline Known HCV positive & $21\left(1.6^{\star}\right)$ \\
\hline Known HIV positive & $42\left(3.3^{\star}\right)$ \\
\hline
\end{tabular}

Abbreviations: $\mathrm{HBsAg}=$ hepatitis $\mathrm{B}$ surface antigen; $\mathrm{HCV}=$ hepatitis $\mathrm{C}$ virus; $\mathrm{HIV}=$ human immunodeficiency virus

* Percentage of known source

of Liver Diseases/Infectious Diseases Society of America. ${ }^{9}$ In case seroconversion occurs and early treatment is considered desirable, these patients with acute hepatitis $\mathrm{C}$ can be treated with direct-acting antivirals using the same regimen recommended for chronic hepatitis $\mathrm{C}$.

If indicated, HIV PEP should be taken as early as possible after exposure to achieve maximal effect. Initiation of PEP after 72 hours of exposure 
TABLE 2. Risk factors in health care workers with higher-risk occupational exposure during various activities/procedures from 1999 to 2013

\begin{tabular}{|c|c|c|c|}
\hline \multirow[t]{2}{*}{ Risk factor } & \multicolumn{3}{|c|}{ No. of risk factors } \\
\hline & Range & Mean & $95 \%$ Confidence interval \\
\hline Blood taking/intravenous catheter insertion $(n=140)$ & $1-3$ & 1.29 & $1.18-1.39$ \\
\hline Injection including recapping of needles $(n=196)$ & $1-2$ & 1.02 & $1-1.04$ \\
\hline Other bedside/treatment room procedures $(n=95)$ & $1-2$ & 1.03 & 0.99-1.07 \\
\hline Cleaning/tidying up after procedures $(n=115)$ & $1-3$ & 1.03 & 0.98-1.06 \\
\hline Surgery in operating theatre $(n=46)$ & $1-1$ & 1.00 & - \\
\hline Sharps disposal $(n=174)$ & $1-3$ & 1.09 & $1.03-1.14$ \\
\hline Others $(n=88)$ & $1-2$ & 1.03 & 0.99-1.07 \\
\hline
\end{tabular}

TABLE 3. Post-exposure prophylaxis regimens of human immunodeficiency virus

\begin{tabular}{lc}
\hline Regimen & No. (\%) of prescriptions \\
\hline AZT/3TC & $6(12.5)$ \\
AZT/3TC/ATV & $1(2.1)$ \\
AZT/3TC/IDV & $19(39.6)$ \\
AZT/3TC/LPVr & $15(31.3)$ \\
AZT/3TC/NFV & $5(10.4)$ \\
AZT/DDI/LPVr & $1(2.1)$ \\
\hline TDF/FTC/LPVr & $1(2.1)$ \\
\hline Total & $\mathbf{4 8 ( 1 0 0 )}$ \\
\hline
\end{tabular}

Abbreviations: 3TC = lamivudine; ATV = atazanavir; $\mathrm{AZT}=$ zidovudine; DDI = didanosine ; FTC = emtricitabine $;$ IDV = indinavir; LPVr = ritonavir-boosted lopinavir; NFV = nelfinavir; TDF $=$ tenofovir

was shown to be ineffective in animal studies. ${ }^{10}$ The timing of PEP initiation in our cohort appeared to be less prompt (33.3\% within 2 hours compared with more than $60 \%$ and $80 \%$ within 3 hours in the UK and US, respectively). Overall, however, $89.6 \%$ managed to start PEP within 24 hours, in line with experience in the UK or US. Health care workers should be reminded about post-exposure management and the need for timely medical assessment following occupational exposure. In the accident and emergency department, priority assessment should be given to health care workers exposed to bloodborne viruses. The median duration of PEP intake of 28 days was in line with the local guidelines. With the availability of newer drugs with fewer toxicities, the tolerance and compliance rate should improve.

Finally, using the estimated risk of HIV transmission with percutaneous injury of $0.3 \%$, we would expect four HIV seroconversions in 1356 percutaneous exposures in TPC if all were exposed to HIV-infected blood. Because in most of these exposures the source HIV status was unknown and likely negative in this region of overall low HIV prevalence (approximately $0.1 \%^{11}$ ), the actual risk of HIV transmission was much lower in the health care setting of Hong Kong. This finding is confirmed by the fact that no HIV seroconversion occurred in this cohort. In addition, those with exposure of the highest risk received HIV PEP. In the UK, there were 4381 significant occupational exposures from 2002 to 2011, of which 1336 were exposures to HIV-infected blood or body fluid. No HIV seroconversions occurred among these exposures. ${ }^{7}$ In the US, there has been one confirmed case of occupational transmission of HIV in health care workers since $1999 .{ }^{12}$ Similarly, the local prevalence of $\mathrm{HCV}$ infection is low $(<0.1 \%$ in new blood donors ${ }^{13}$ ), partly explaining the absence of $\mathrm{HCV}$ transmission in this cohort. In contrast, there were 20 cases of $\mathrm{HCV}$ seroconversion in health care workers reported between 1997 and 2011 in the UK. ${ }^{7}$ Hepatitis B is considered to be endemic in Hong Kong, with HBsAg positivity of $1.1 \%$ in new blood donors and $6.5 \%$ in antenatal women in $2013 .{ }^{13}$ Nonetheless, the HBV vaccination programme in health care workers coupled with HBV PEP has proven successful in preventing HBV transmission to health care workers. With concerted efforts in infection control and timely PEP, transmission of blood-borne viruses via sharps and mucosal injury in the health care setting is largely preventable.

There are several limitations to our study. First, data were collected from a single centre and based on secondary referral. We did not have data for other health care workers who had occupational exposure but who were not referred to the TPC for post-exposure management, or who were referred but did not attend. Thus, we were not able to draw any general conclusions on the true magnitude of the problem. Second, details of the exposure and the infection status of the source were self-reported by the exposed client and prone to bias and underreporting. 


\section{Conclusions}

Percutaneous injury with sharps during cleaning or tidying up after procedures was the most common cause of occupational exposure to blood or body fluids in this cohort of health care workers. The majority of source patients were not confirmed HIVpositive and HIV PEP was not generally indicated. Prescriptions of HIV PEP were appropriate and timely in most cases. There were no HIV, HBV, and $\mathrm{HCV}$ seroconversions in health care workers who attended the TPC following sharps or mucosal injury from mid-1999 to 2013.

\section{Appendices}

Additional material related to this article can be found on the HKMJ website. Please go to <http:// www.hkmj.org>, and search for the article.

\section{Declaration}

All authors have disclosed no conflicts of interest.

\section{References}

1. Pruss-Ustun A, Rapiti E, Hutin Y. Sharps injuries: Globa burden of disease from sharps injuries to health-care workers (World Health Organization Environmental Burden of Disease Series, No. 3). Available from: http:// www.who.int/quantifying_ehimpacts/publications/en/ sharps.pdf?ua=1. Accessed 2 Feb 2016.

2. Scientific Committee on AIDS and STI (SCAS), and Infection Control Branch, Centre for Health Protection, Department of Health. Recommendations on the management and postexposure prophylaxis of needlestick injury or mucosal contact to HBV, HCV and HIV. Hong Kong: Department of Health; 2014.

3. Cardo DM, Culver DH, Ciesielski CA, et al. A case-control study of HIV seroconversion in health care workers after percutaneous exposure. Centers for Disease Control and Prevention Needlestick Surveillance Group. N Engl J Med 1997;337:1485-90.

4. Kuhar DT, Henderson DK, Struble KA, et al. Updated US Public Health Service guidelines for the management of occupational exposures to human immunodeficiency virus and recommendations for postexposure prophylaxis. Infect Control Hosp Epidemiol 2013;34:875-92.

5. UK Department of Health. HIV post-exposure prophylaxis: guidance from the UK Chief Medical Officers' Expert Advisory Group on AIDS. 19 September 2008 (last updated 29 April 2015).

6. WHO Guidelines Approved by the Guidelines Review Committee. Guidelines on Post-Exposure Prophylaxis for HIV and the Use of Co-Trimoxazole Prophylaxis for HIV-Related Infections Among Adults, Adolescents and Children: Recommendations for a Public Health Approach: December 2014 supplement to the 2013 consolidated guidelines on the use of antiretroviral drugs for treating and preventing HIV infection. Geneva: World Health Organization; December 2014.

7. Eye of the Needle. United Kingdom surveillance of significant occupational exposures to bloodborne viruses in healthcare workers. London: Health Protection Agency; December 2012

8. US Department of Health and Human Services, Centers for Disease Control and Prevention. The National Surveillance System for Healthcare Workers $(\mathrm{NaSH})$ : Summary report for blood and body fluid exposure data collected from participating healthcare facilities (June 1995 through December 2007).

9. American Association for the Study of Liver Diseases/ Infectious Diseases Society of America. HCV guidance: recommendations for testing, managing, and treating hepatitis C (updated 24 February 2016). Available from: http://www.hcvguidelines.org. Accessed 5 May 2016.

10. Tsai CC, Emau P, Follis KE, et al. Effectiveness of postinoculation (R)-9-(2-phosphonylmethoxypropyl) adenine treatment for prevention of persistent simian immunodeficiency virus SIVmne infection depends critically on timing of initiation and duration of treatment. J Virol 1998;72:4265-73.

11. HIV surveillance report-2014 update. Department of Health, The Government of the Hong Kong Special Administrative Region; December 2015.

12. Joyce MP, Kuhar D, Brooks JT, Occupationally acquired HIV infection among health care workers-United States, 1985-2013. MMWR Morb Mortal Wkly Rep 2015;63:12456.

13. Surveillance of viral hepatitis in Hong Kong-2014 update. Department of Health, The Government of the Hong Kong Special Administrative Region; December 2015. 